\title{
The effect of grazing severity during winter on herbage regrowth and quality
}

\author{
J.M. LEE ${ }^{1}$, D. J. DONAGHY ${ }^{2}$ and J.R. ROCHE ${ }^{1}$ \\ ${ }^{1}$ Dexcel, PB 3221, Hamilton \\ ${ }^{2}$ Tasmanian Institute of Agricultural Research, Burnie, Tasmania \\ julia.lee@dexcel.co.nz
}

\begin{abstract}
Grazing management is concerned with managing the interactions between plants and animals. Two management factors that require consideration are the optimal grazing time and the effect of grazing severity on subsequent regrowth. The objective of the current study was to quantify the effect of grazing severity in winter on leaf appearance $r$ ate, herbage accumulation and quality, and plant energy reserves. Ten pasture areas were g razed to two different residual masses $(1260 \pm 101$ and $1868 \pm$ $139 \mathrm{~kg}$ dry matter (DM)/ha, Severe and Lax, respectively) over five consecutive days by dry dairy cows. Neither growth rate (average $15 \mathrm{~kg} \mathrm{DM} / \mathrm{ha} /$ day), nor leaf appearance rate (average 16 days/new leaf) differed between treatments. As a result, herbage accumulated over the 49-day regrowth period was similar between grazing treatments $(736$ and $715 \mathrm{~kg} \mathrm{DM} / \mathrm{ha}$ for Severe and Lax, respectively), although herbage mass when three new leaves had emerged on regrowing tillers (third leaf stage) was greater on the laxly grazed treatment. Perennial ryegrass plants defoliated more severely displayed a trend for lower levels of water-soluble carbohydrates (WSC) than plants defoliated more laxly, but this difference had disappeared by the third leaf stage of regrowth. Pasture quality was improved in the severely defoliated treatment, with higher digestibility, WSC and metabolisable energy (ME) concentrations, and (ADF) lower acid and neutral detergent fibre (NDF) concentrations.
\end{abstract}

Keywords: grazing severity, herbage production, water-soluble carbohydrates

\section{Introduction}

Too frequently, the focus of grazing management is on meeting animal requirements, rather than understanding the way in which the plants respond to the grazing management regimes imposed (Fulkerson \& Donaghy 2001).

In most temperate regions of the world, combined effects of differences in temperature, moisture availability and radiation lead to variations in seasonal herbage production (McKenzie et al. 2000). These are generally characterised by feed surpluses during the spring, and depending on the farm system, potential feed deficits during winter and summer. Managing this variation in forage production can be difficult and involves changes in grazing frequency and severity throughout the year.
Previous studies (Wilson \& Robson 1970; Simons et al. 1972; Fulkerson et al. 1994) recommend an optimal defoliation height of approximately $5 \mathrm{~cm}$ to optimise ryegrass growth and persistence. Defoliation below this height may reduce WSC stores, particularly during winter when radiation intensity, and therefore subsequent replenishment of carbohydrate stores, is low. It has also been suggested (Smith 1974; Booysen \& Nelson 1975) that a less severe grazing (leaving residual leaf), will result in faster recovery of ryegrass swards, an important factor during winter when feed is scarce.

There are conflicting reports on the effect of defoliation severity on herbage production. Several studies demonstrated a reduction in subsequent DM yields and growth rates of pastures with more frequent $(<2-3$ weeks apart) and severe $(<1500 \mathrm{~kg} \mathrm{DM} / \mathrm{ha}$; $<4 \mathrm{~cm}$ residual height) defoliation (Baker 1957; Jones 1933), whilst in others, herbage accumulation was greater when grazing residuals were lower (Binnie \& Harrington 1972; Reid 1959, 1962; Reyes et al. 2000). In addition, severe grazing improved tillering (Brougham 1960; Michell \& Fulkerson 1987; Xia et al. 1990) and subsequent herbage quality (Michell \& Fulkerson 1987; Reyes et al. 2000).

The confounding effect of grazing frequency and severity in many reported studies makes it difficult to determine the true eff ect of grazing severity. In several studies pastures were defoliated at precise heights or after a certain length of time, which may have led to pastures being inadvertently grazed prior to emergence of the second new leaf (Binnie \& Harrington 1972; Brougham 1960; Reid 1959, 1962), a physiological stage believed to reduce carbohydrate storage and plant vigour (Fulkerson \& Donaghy 2001).

The aim of the current study was to quantify the effect of grazing severity in winter on leaf appearance rate, herbage accumulation and quality, and plant energy reserves, without the confounding effect of grazing frequency.

\section{Materials and methods}

The experiment was conducted on a humic silt loam soil at Scott Farm, Dexcel, Hamilton, New Zealand (37 46'S 175 18'E) between July and September 2004. The permanent grassland site consisted of a sward with $80-90 \%$ perennial ryegrass on a DM basis and had not been grazed in the last 70 days. The sward also 
Table 1 Mean weekly weather data for the duration of the pasture regrowth period.

\begin{tabular}{lccccccc}
\hline & Week One & Week Two & Week Three & Week Four & Week Five & Week Six & Week Seven \\
\hline Maximum air temperature $\left({ }^{\circ} \mathrm{C}\right)$ & 13.4 & 14.6 & 14.0 & 14.7 & 14.3 & 13.2 & 13.9 \\
Minimum air temperature $\left({ }^{\circ} \mathrm{C}\right)$ & 0.9 & 3.0 & 3.8 & 6.6 & 3.8 & 1.1 & 0.9 \\
Radiation $\left(\mathrm{MJ} / \mathrm{m}^{2}\right)$ & 9.4 & 8.1 & 8.0 & 8.5 & 10.3 & 13.2 & 12.9 \\
Soil temperature at $10 \mathrm{~cm} \quad\left({ }^{\circ} \mathrm{C}\right)$ & 9.2 & 9.9 & 9.9 & 10.6 & 10.5 & 10.0 & 9.6 \\
Total rainfall $(\mathrm{mm})$ & 3.6 & 24.6 & 43.6 & 36.6 & 6.8 & 9.2 & 14.6 \\
\hline
\end{tabular}

${ }^{1}$ Week One beginning 19th July 2004.

contained white clover (Trifolium repens), Poa (Poa annua) and prairie grass (Bromus willdenowii Kunth.)

Five blocks of two plots (ten plots in total) were defoliated by dry dairy cows over five consecutive days to achieve residuals of either $1200 \mathrm{~kg} \mathrm{DM} / \mathrm{ha}$ (Severe) or $1800 \mathrm{~kg} \mathrm{DM} / \mathrm{ha}$ (Lax). Three subplots (each $0.5 \mathrm{~m}^{2}$ ) were randomly located in each of the ten plots for intensive herbage measurements.

Weather data were recor ded at 0900 daily over the trial period, at a weather station less than $5 \mathrm{~km}$ from the trial site. Soil temperature $\left({ }^{\circ} \mathrm{C}\right)$ data at $10 \mathrm{~cm}$ depth were also collected at the experimental farm. Weather data are presented in Table 1.

\section{Herbage measurements}

Compressed herbage height was measured on each subplot, immediately post-grazing, and on day 3, 6, 10, 13, 20, 28, 38, 45 and 49 post-grazing, using a Rising Plate Meter installed with an electronic counter (Farmworks, Palmerston North). These values were converted to DM yield using a regression equation derived from calibration cuts, as follows:

Herbage mass $(\mathrm{kg} / \mathrm{DM} / \mathrm{ha})=298.2 \times$ compressed herbage height $(\mathrm{cm})+785.1 ; \mathrm{R}^{2}=0.75 ; \mathrm{n}=457$.

Three weeks following defoliation, perennial ryegrass leaf regrowth stage was determined using the method outlined by Fulkerson \& Donaghy (2001), and thrice weekly thereafter.

When, on average, one, two or three new leaves had appeared on treatment subplots, 30 mature perennial ryegrass tillers (including roots) were randomly harvested at each stage, from each subplot. Tillers were collected approximately 3 hours after sunrise to minimise the effects of known diurnal variation in WSC content (Fulkerson et al. 1994) and placed on ice. The time from ice to freezer was no longer than 10 minutes. The numbers of daughter tillers per mature tiller were counted, tillers washed to remove soil contamination, and roots removed from the base of the tiller. Leaves were separated from the stem (stubble) at the auricle, and average stubble length measured. From each subplot, the length and width (at the widest part) of all leaves on three ryegrass tillers were measured to determine average leaf area. Leaves and stubble for each subplot and leaf stage were stored at $-20^{\circ} \mathrm{C}$, freeze-dried, ground to pass through a $1 \mathrm{~mm}$ sieve and analysed for WSC. Water-soluble carbohydrate concentration $(\mathrm{g} / \mathrm{kg}$ DM) was determined as described in Technicon Industrial Method number 302-73A from the method outlined by Smith (1969).

When, on average, the third new perennial ryegrass leaf had appeared on treatment subplots, ryegrass tiller numbers in three randomly positioned $0.01 \mathrm{~m}^{2}$ quadrats were counted in each subplot, providing an estimate of ryegrass tiller density. A representative herbage sample was cut to $3 \mathrm{~cm}$ height from the centre of each subplot $(n=10)$, blended and subsampled. One subsample was dissected to determine botanical composition, and another dried at $60^{\circ} \mathrm{C}$ to a constant weight, ground to pass through a $1 \mathrm{~mm}$ sieve and analysed for quality parameters using near infrared spectroscopy (Corson $e t$ al. 1999).

\section{Statistical analysis}

Data collected from the third block of plots were omitted from all analyses due to treading damage in the Severe treatment. All data were analysed by ANOVA using the statistical procedures of Genstat 7 (2004), with grazing severity as the fixed effect and block and plot as the random effect. The F-test was used to determine the significance of the explanatory variables. Cubic splines were fitted within subplot using PROC TRANSREG (SAS 2001) to both regrowth and leaf appearance rate data. Data were interpolated and extrapolated from the fitted splines.

\section{Results}

As planned, the post-grazing residuals on the severely grazed plots were significantly lower than the laxly grazed comparisons $(\mathrm{P}<0.01 ; 1.6$ vs $3.6 \mathrm{~cm}$ compressed height, equating to 1260 and $1868 \mathrm{~kg} \mathrm{DM} / \mathrm{ha}$, respectively). The $\mathrm{R}^{2}$ of the splines averaged 0.88 and 0.99 for herbage mass and rate of appearance of new leaves, respectively. Growth rates during the 49 days of regrowth period averaged $15 \mathrm{~kg} \mathrm{DM} /$ ha/day and average rate of appearance of new leaves was 16 days/ new leaf (Figure 1). Neither were affected by grazing severity. As a consequence, herbage accumulation was not different between grazing treatments, and averaged $726 \mathrm{~kg} \mathrm{DM} / \mathrm{ha}$ (715 and $736 \mathrm{~kg} \mathrm{DM} /$ ha for Lax and 
Figure 1 (a) Herbage mass and (b) leaf appearance rate of severely (square) or laxly (diamond) grazed pastures during the first 50 days postgrazing; fitted splines for severely (dash-dot line) and laxly (dashed line) grazed swards are presented. Vertical bars indicate twice the SED.
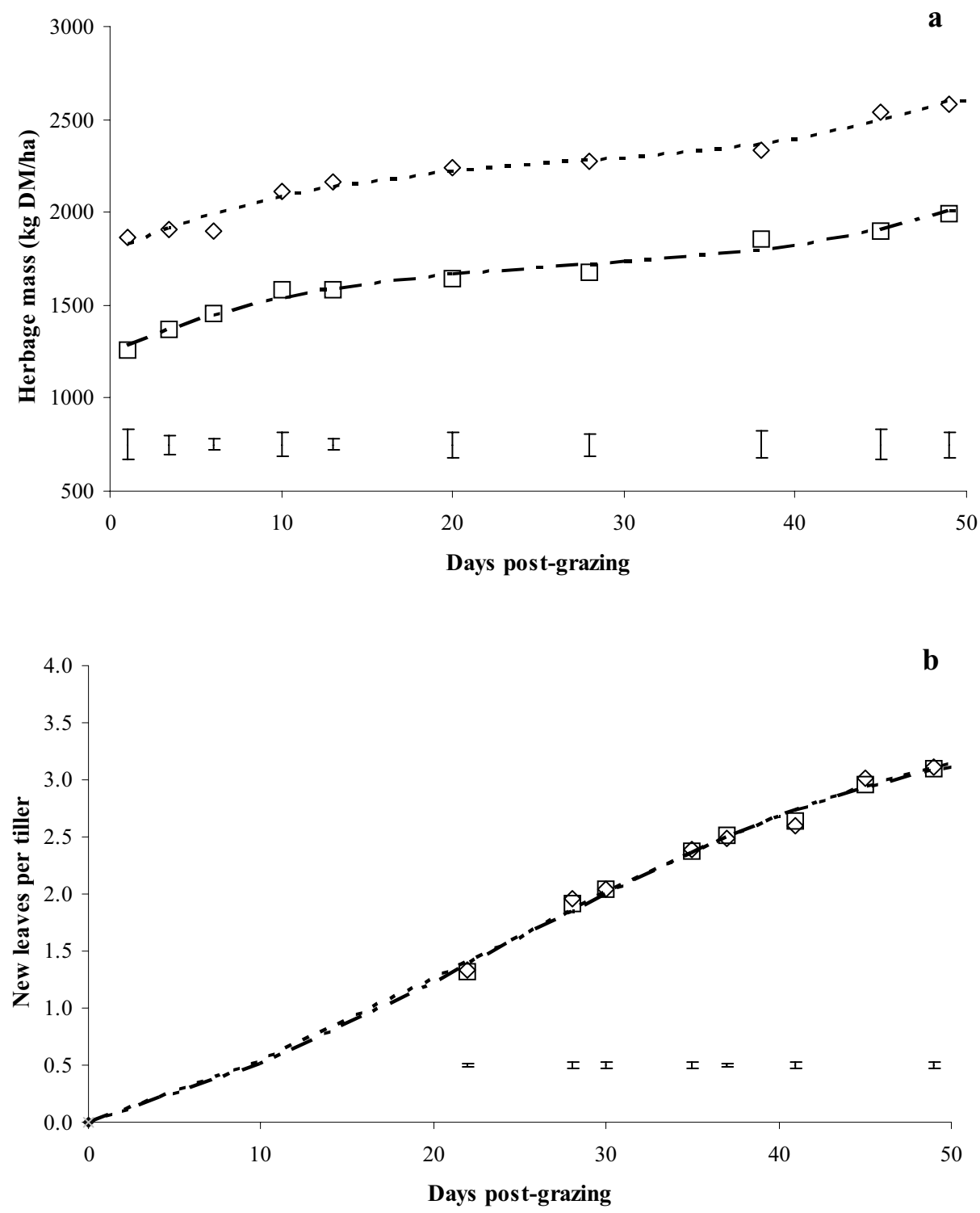

Severe, respectively). The laxly grazed treatment subplots had a higher DM yield than those severely grazed (2583 vs. $1996 \mathrm{~kg} \mathrm{DM} /$ ha after emergence of the third new leaf; $\mathrm{P}<0.01$ ).

The area of newly emerged leaves was not affected by grazing severity at the first or second leaf stage of regrowth. However, on appearance of the third new leaf, laxly grazed ryegrass produced larger leaves than those severely grazed (873 vs. $794 \mathrm{~mm}^{2} ; \mathrm{P}<0.05$ ).

There was no effect of grazing severity on tiller density or the number of daughter tillers produced/ mature tiller during the regrowth period, with an average of 7 daughter tillers produced/10 mature tillers.

There was a trend for lower WSC levels in the leaf and stubble of severely defoliated perennial ryegrass plants than laxly grazed counterparts, at the first and second leaf regrowth stage, but this difference was not significant following emergence of the third new leaf (Table 2).

Herbage quality was improved in the severely grazed tr eatment (Table 3 ) with ME concentr ations increased by $0.3 \mathrm{MJ} / \mathrm{kg} \mathrm{DM}$, digestibility increased by $2.6 \mathrm{~g} / 100 \mathrm{~g}$ 
Table 2 Water-soluble carbohydrate levels $(\mathrm{g} / 100 \mathrm{~g} \mathrm{DM})$ in perennial ryegrass leaf and stubble at the first, second and third leaf stage of regrowth following defoliation to either 1.6 (Severe) or 3.6 (Lax) cm compressed height.

\begin{tabular}{lllllc}
\hline & & Lax & Severe & SED & P value \\
\hline WSC (g/100g) DM) & & & & & \\
First leaf stage & Leaf & 13.4 & 10.9 & 0.71 & $<0.05$ \\
& Stubble & 23.0 & 20.0 & 2.12 & 0.25 \\
Second leaf stage & Leaf & 17.3 & 14.0 & 1.08 & 0.06 \\
& Stubble & 30.3 & 25.7 & 1.36 & $<0.05$ \\
Third leaf stage & Leaf & 30.8 & 28.8 & 1.03 & 0.15 \\
& Stubble & 39.9 & 39.0 & 2.50 & 0.63 \\
\hline
\end{tabular}

Table 3 Botanical and chemical composition (g/100g DM) and ME (MJ/kg DM) content of pasture regrowth ${ }^{1}$ after appearance of the third new leaf following defoliation to either 1.6 (Severe) or 3.6 (Lax) cm compressed height.

\begin{tabular}{lcccc}
\hline & Lax & Severe & SED & P value \\
\hline Botanical composition & & & & \\
Ryegrass leaf & 71.9 & 82.5 & 2.64 & $<0.05$ \\
Ryegrass pseudostem & 5.2 & 5.9 & 0.89 & 0.50 \\
White clover & 5.0 & 3.1 & 1.98 & 0.40 \\
Other grasses & 7.7 & 3.6 & 1.41 & 0.06 \\
Weeds & 2.6 & 1.8 & 0.84 & 0.42 \\
Dead material & 7.7 & 3.2 & 0.85 & $<0.05$ \\
Chemical composition & & & & \\
CP & 23.7 & 23.0 & 0.70 & 0.39 \\
Lipid & 4.8 & 5.0 & 0.12 & 0.15 \\
Ash & 9.0 & 8.6 & 0.20 & 0.10 \\
ADF & 16.7 & 14.8 & 0.50 & $<0.05$ \\
NDF & 33.4 & 31.5 & 0.64 & 0.06 \\
WSC & 18.6 & 21.3 & 0.58 & $<0.05$ \\
OMD & 81.8 & 84.4 & 0.57 & $<0.05$ \\
ME & 11.9 & 12.2 & 0.08 & $<0.05$ \\
\hline
\end{tabular}

${ }^{1}$ Pasture was cut at a $3 \mathrm{~cm}$ stubble height.

DM and WSC concentrations increased by $2.7 \mathrm{~g} / 100 \mathrm{~g}$ DM. Acid and neutral detergent fibre concentrations were also reduced in the severely grazed treatment by $1.9 \mathrm{~g} / 100 \mathrm{~g}$ each.

After appearance of the third new leaf, severely grazed subplots contained more perennial ryegrass leaf and less dead material than laxly grazed subplots (Table 3 ). There was also a trend towards reduced proportions of other grasses, such as prairie grass and Poa, in the severely grazed treatments, compared with those laxly grazed.

\section{Discussion}

Growth rate, leaf appearance rate and leaf area were not affected by grazing severity. The effect on growth rate contrasts with previous studies (Smith 1974; Booysen $\&$ Nelson 1975) suggesting increased levels of residual leaf remaining following lax defoliation $(>1500 \mathrm{~kg} \mathrm{DM} /$ ha; $>4 \mathrm{~cm}$ residual height) may increase regrowth, but supports the fact that these residual leaves are generally older and less photosynthetically active than younger emerging leaves (Gay \& Thomas 1995) and therefore contribute very little to subsequent regrowth.

Despite the similar overall herbage accumulation, the laxly grazed treatment subplots had a higher final DM yield/ha due to higher residuals at the start of the experimental period. At the end of the 49-day regr owth period there was an extra $587 \mathrm{~kg} \mathrm{DM} / \mathrm{ha}$ in laxly defoliated swards compared to those severely defoliated (2583 vs. $1996 \mathrm{~kg} \mathrm{DM} / \mathrm{ha}$, respectively). This remains important because pregrazing pasture mass can influence herbage intake and hence animal production.

Previous research recorded both increased and decreased leaf appearance rates when comparing severe and laxly defoliated treatments. In a glasshouse study, Davies (1974) reported an increasing leaf appearance rate as plants were more severely defoliated, although the difference was small and confined to the first week of herbage regrowth. In contrast, Grant et al. (1981) reported that severe defoliation $(2 \mathrm{~cm})$ decreased leaf appearance rate compared with lax $(6 \mathrm{~cm})$. In this case the effect lasted 4 weeks. This inconsistency in results 
suggests that other factors must influence the effect of grazing severity on leaf appearance. These could include soil fertility, fertiliser application, climate or previous grazing management that would influence the levels of energy reserves in the plant.

The major finding of this study was that WSC levels in both the leaf and stubble components of perennial ryegrass were high, suggesting that even when severely defoliated, sufficient reserves were present to allow regrowth (Alberda 1966). Accumulation of WSC in ryegrass is greatest in conditions that promote photosynthesis, such as full light, or reduce respiration, such as cooler temperatures (Alberda 1957). Kingsbury (1965) reported that WSC concentrations in perennial ryegrass in New Zealand were maximised in early winter after a bright, sunny afternoon. As well as the balance between photosynthesis and respiration, absolute levels of WSC also depend on plant growth rate (White 1973). The high levels of WSC recorded in this experiment are likely due to a combination of low minimum temperature (Table 1) and consequent low growth rates and plant respiration.

Alberda (1966) indicated that perennial ryegrass regrowth appeared retarded when stubble WSC concentrations were below $15 \%$. Due to the high energy reserves of plants in the current study, severe grazing did not substantially lower WSC to levels where reserves may have limited the plant's ability to regrow. The effect of grazing severity on ryegrass plants with lower WSC reserves is an area for further research.

This study supports previous research (Michell \& Fulkerson 1987; Reyes et al. 2000), showing improved pasture quality with greater grazing severity $(<1500 \mathrm{~kg}$ $\mathrm{DM} / \mathrm{ha} ;<4 \mathrm{~cm}$ residual height). The improvement in herbage quality in the severely grazed subplots in the current study was due to favourable alterations in botanical composition, in particular increased ryegrass leaf and decreased proportions of other grasses and dead material in the sward. Reduced herbage quality in laxly grazed subplots is likely due to the carryover of older leaf material from the pregrazing pasture.

\section{Conclusion}

From this study we conclude that when plant energy reserves are high, pastures may be grazed more severely during winter, as long as soil and environmental conditions are such that treading damage won't occur, with no detrimental effects on herbage regrowth or energy reserve levels. Severe defoliation in winter resulted in significant beneficial effects on herbage quality and botanical composition.

\section{ACKNOWLEDGEMENTS}

The authors would like to acknowledge the statistical expertise of Barbara Dow and Dr. Donagh Berry, the help afforded by Scott Farm staff and the technical expertise of Glenise Ferguson and Karen Christie. In addition the assistance of Dexcel management and that of the University of Tasmania is gratefully appreciated.

\section{REFERENCES}

Alberda, Th. 1957. The effects of cutting, light intensity and night temperature on growth and soluble carbohydrate content of Lolium perenneL. Plant and Soil 8: 199-230.

Alberda, Th. 1966. Responses of grasses to temperature and light. pp. 200-212. In: The Growth of Cereals and Grasses. Eds. Milthorpe, F.L.; Ivins, J.D. Butterworths, London, UK.

Baker, H.K. 1957. Studies on the root development of herbage plants. 3 . The influence of cutting treatments on the root, stubble and herbage production of a perennial ryegrass sward. Journal of the British Grassland Society 12: 197-208.

Binnie, R.C.; Harrington, F.J. 1972. The effect of cutting height and cutting frequency on the productivity of an Italian ryegrass sward. Journal of the British Grassland Society 27: 177-179.

Booysen, P. de V.; Nelson, C.J. 1975. Leaf area and carbohydrate reserves in regrowth of tall fescue.Crop Science 15: 262-266.

Brougham, R.W. 1960. The effects of frequent hard grazings at different times of the year on the productivity and species yields of a grass-clover pasture. New Zealand Journal of Agricultural Research 3: 125-136.

Corson, D.C.; Waghorn, G.C.; Ulyatt, M.J.; Lee, J. 1999. NIRS: Forage analysis and livestock feeding. Proceedings of the New Zealand Grassland Association 61: 127-132.

Davies, A. 1974. Leaf tissue remaining after cutting and regrowth in perennial ryegrass. Journal of Agricultural Science, Cambridge 82: 165-172.

Fulkerson, W.J.; Slack, K.; Lowe, K.F. 1994. Variation in the response of Lolium genotypes to defoliation. Australian Journal of Agricultural Research 45: 1309-1317.

Fulkerson, W.J.; Donaghy, D.J. 2001. Plant-soluble carbohydrate reserves and senescence - key criteria for developing an effective grazing management system for ryegrass based pastures: a review. Australian Journal of Experimental Agriculture 41: 261-275.

Gay, A.P.; Thomas, H. 1995. Leaf development in Lolium temulentum L.: photosynthesis in relation to growth and senescence. New Phytologist 130. 159168.

GenStat 2004. GenStat for Windows. Release 7.2. 7th 
Edition. VSN International Ltd., Oxford, UK.

Grant, S.A.; Barthram, G.T.; Torvell, L. 1981. Components of regrowth in grazed and cut Lolium perenne swards. Grass and Forage Science 36: 15568.

Jones, G. 1933. Grassland management and influence on the sward. 1. Factors influencing the growth of pasture plants. Empire Journal of Experimental Agriculture 1: 43-57.

Kingsbury, L.R. 1965. Pasture quality in terms of soluble carbohydrates and volatile fatty acid production. Proceedings of the New Zealand Society of Animal Production 25: 119-34.

McKenzie, B.A.; Kemp, P.D.; Moor, D.J.; Matthew, C. and Lucas, R.J. 2000. Chapter 3: Environmental effects on plant growth and development. pp. 29-44. In: New Zealand Pasture and Crop Science. Eds. White, J.; Hodgson, J. Oxford University Press.

Michell, P.; Fulkerson, W.J. 1987. Effect of grazing intensity in spring on pasture growth, composition and digestibility, and on milk production by dairy cows. Australian Journal of Experimental Agriculture 27: 35-40.

Reid, D. 1959. Studies in cutting management of grassclover swards. I. The effect of varying the closeness of cutting on the yields from an established grassclover sward. Journal of Agricultural Science, Cambridge 53: 299.

Reid, D. 1962. Studies in cutting management of grassclover swards. III. The effects of prolonged close and lax cutting on herbage yield and quality. Journal of Agricultural Science, Cambridge 59: 359-368.

Reyes, J.; Vidal, I.; Gonzalez, M.; Fonte, D . 2000. Three grazing intensities on star grass (Cynodon nlemfuensis) performance. Cuban Journal of Agricultural Science 34: 121-127.

SAS Institute. 2001. SAS/STAT Users guide (release 8.0) SAS Institute Inc., Cary, NC, USA.

Simons, R.G.; Davies, A.; Troughton, A. 1972. The effect of the height of defoliation on two clones of perennial ryegrass. Journal of Agricultural Science, Cambridge 79: 509-514.

Smith, D. 1969. Removing and analysing total nonstructural carbohydrates from plant tissue. Wisconsin Agricultural Experimental Station, Research Report 41: 1-11.

Smith, D. 1974. Growth and development of timothy tillers as influenced by level of carbohydrate reserves and leaf area. Annals of Botany 38: 595-606.

White, L.M. 1973. Carbohydrate reserves of grasses: a review. Journal of Range Management 26: 13-18.

Wilson, D.B.; Robson, M.J. 1970. Regrowth of S24 ryegrass and its relation to yield measurement of grazed swards. Journal of the British Grassland Society 25: 220-227.

Xia, J.X.; Hodgson, J.; Matthew, C.; Chu, A.C.P. 1990. Tiller population and tissue turnover in a perennial ryegrass pasture under hard and lax spring and summer grazing. Proceedings of the New Zealand Grassland Association 51: 119-122. 